\title{
In vitro antimicrobial activity of miconazole and polymyxin B against canine meticillin-resistant Staphylococcus aureus and meticillin-resistant Staphylococcus pseudintermedius isolates
}

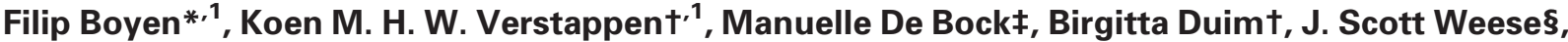 \\ Stefan Schwarzף, Freddy Haesebrouck*,2 and Jaap A. Wagenaart,2 \\ * Department of Pathology, Bacteriology and Avian Diseases, Faculty of Veterinary Medicine, Ghent University, Salisburylaan 133,9820 \\ Merelbeke, Belgium \\ tDepartment of Infectious Diseases and Immunology, Faculty of Veterinary Medicine, Utrecht University, Utrecht, The Netherlands \\ ‡Elanco Animal Health, Antwerpsesteenweg 51, 2350 Vosselaar, Belgium \\ $\S$ Department of Pathobiology, University of Guelph, Ontario, Canada \\ ףInstitute of Farm Animal Genetics, Friedrich-Loeffler-Institut, 31535 Neustadt-Mariensee, Germany
}

Correspondence: Filip Boyen, Department of Pathology, Bacteriology and Avian Diseases, Faculty of Veterinary Medicine, Ghent University, Salisburylaan 133, 9820 Merelbeke, Belgium. E-mail: filip.boyen@ugent.be

\begin{abstract}
Background - Meticillin-resistant Staphylococcus aureus (MRSA) and meticillin-resistant Staphylococcus pseudintermedius (MRSP) infections are increasingly reported in dogs, and these bacteria may be isolated from ear infections.
\end{abstract}

Hypothesis/Objectives - The main aim of the present study was to investigate the in vitro antimicrobial activity of miconazole, polymyxin B and a combination of both against 24 canine MRSA and 50 canine MRSP isolates. The minimal inhibitory concentration (MIC) values of 12 other antimicrobial agents were also determined.

Methods - All MIC values were determined according to a broth microdilution assay.

Results - Acquired resistance was found to all tested agents, except for linezolid, miconazole and polymyxin B. The MIC values for miconazole and polymyxin B against MRSA were in the range of 4-8 and 8-64 $\mu \mathrm{g} / \mathrm{mL}$, respectively, while the MIC values for miconazole and polymyxin B against MRSP were in the range of 1-2 and $0.25-4 \mu \mathrm{g} / \mathrm{mL}$, respectively. Using a combination of miconazole and polymyxin $B$, there was no evidence for enhanced in vitro activity of the combination (i.e. synergy) of both products. Nevertheless, MIC 90 values of the combination of these antimicrobial agents and of a commercial product containing both agents were at least 1000 times lower than the concentration present in the commercial product.

Conclusions and clinical importance - These results indicate that the topical use of a combination of miconazole and polymyxin B in a 43.5:1 ratio may have potential for the treatment of MRSA-mediated and MRSP-associated otitis externa in dogs.

\section{Introduction}

Staphylococcus pseudintermedius is an opportunistic pathogen that is part of the Staphylococcus intermedius group (SIG) and is mainly found in dogs and cats. ${ }^{1,2}$ In most animals, it belongs to the resident flora. ${ }^{3,4}$ Meticillin-resistant $S$. pseudintermedius (MRSP) is being increasingly isolated from pets and sporadically from humans. ${ }^{5,6}$ For many years, meticillin-resistant Staphylococcus aureus (MRSA) was considered a human pathogen. Recent reports indicate that MRSA has emerged as a pathogen of animals as well. ${ }^{5}$ The presence of the mecA gene in both MRSP and MRSA, which results in

Accepted 6 January 2012

${ }^{1}$ Both authors contributed equally

${ }^{2}$ Shared senior co-authorship.

Sources of Funding: The costs of laboratory consumables were funded by Elanco Animal Health, Antwerpsesteenweg 51, 2350 Vosselaar, Belgium.

Conflict of Interest: M. De Bock is an employee of Elanco. the production of an alternative penicillin-binding protein (PBP), namely PBP2a, renders these organisms resistant to all $\beta$-lactam antimicrobials used in veterinary medicine. Moreover, many of these isolates show additional resistance to other classes of antimicrobials commonly used in veterinary medicine. ${ }^{7,8}$ Most reported MRSP and MRSA infections in dogs involve skin, ear, wound and postoperative infections. ${ }^{5}$

Otitis externa is a common problem in dogs. Various treatment approaches can be used, including systemic antimicrobials, topical treatments or a combination of both systemic and topical treatment. Topical treatment has several advantages over systemic treatment; it is cheaper, easier to perform, results in higher local antimicrobial concentrations, and there is no or very limited antimicrobial selection pressure on sites outside the treated area. ${ }^{9}$ Even though there are several all-in-one commercial products that are used to treat canine otitis, there is limited information on the susceptibility of pathogens causing otitis against both the products as sold, and 
the single active compounds. Surolan ${ }^{\circledR}$ (Elanco Animal Health; Greenfield, IL, USA) is a combination of miconazole nitrate, polymyxin B sulfate and prednisolone acetate that is licensed to treat canine otitis.

The effect of polymyxin B on bacteria is attributed to its ability to destabilize the lipopolysaccharide structure. ${ }^{10,11}$ Polymyxin B also has an effect on the cell membrane of fungi, making them more sensitive to other antimicrobials. ${ }^{12}$ The activity of miconazole against fungi derives primarily from inhibition of the biosynthesis of ergosterol, an essential component of the fungal plasma membrane. ${ }^{13}$ Miconazole, however, is also effective against bacteria through binding to flavohaemoglobin, which eventually results in oxidative stress followed by cell death. ${ }^{14}$ The combination of polymyxin $\mathrm{B}$ and miconazole has been shown to be successful for the treatment of infections caused by various pathogens, including multidrug-resistant pathogens, such as Pseudomonas spp. and enterococci. ${ }^{15,16}$

It was the aim of the present study to determine the susceptibility of canine MRSP and MRSA isolates against several antimicrobial agents, including miconazole, polymyxin $B$, the combination of both miconazole and polymyxin $B$, and the combination of these two agents in a 43.5:1 ratio (Surolan ${ }^{\circledR}$ ).

\section{Materials and methods}

A total of 50 canine MRSP strains isolated from ear or skin infections from Spain $(n=7)$, Germany $(n=13)$, The Netherlands $(n=15)$ and Canada $(n=15)$ and 24 canine MRSA isolates selected from different locations in North America $(n=14)$ and Europe $(n=10)$ were identified with phenotypic tests and PCR as described before. ${ }^{17-20}$

For further characterization of the isolates, the minimal inhibitory concentrations (MICs) of amikacin, ciprofloxacin, clindamycin, erythromycin, fusidic acid, gentamicin, linezolid, mupirocin, neomycin, rifampicin, potentiated sulfonamides and tetracycline was determined using the broth microdilution Sensititre NLV 65 system according to the manufacturer's instructions (Trek Diagnostic Systems Ltd, East Grinstead, West Sussex, UK). As no clinical breakpoints for local treatment of otitis in dogs are available, the epidemiological cut-off values applicable to $S$. aureus ${ }^{21}$ were applied to determine the percentage of isolates classified as nonwild-type.

The MICs of polymyxin $B$, miconazole, the combination of polymyxin $B$ and miconazole, and the product Surolan ${ }^{\circledR}$ (containing $23 \mathrm{mg} / \mathrm{mL}$ miconazole and $0.53 \mathrm{mg} / \mathrm{mL}$ polymyxin B) were evaluated using an in-house broth microdilution assay according to Clinical and Laboratory Standards Institute (CLSI) guidelines. ${ }^{22}$ The combination of polymyxin $B$ and miconazole was tested in a 1:43.5 ratio, which is the same as present in the commercially available product. As no clinical breakpoints for local treatment of otitis in dogs are available, nor are epidemiological cut-off values available for polymyxin B and miconazole in $S$. aureus, ${ }^{21}$ the presence of nonwild-type isolates was assumed when MIC values showed a bimodal or multimodal distribution or tailing as described previously. ${ }^{23,24}$ Staphylococcus aureus ATCC 29213, Enterococcus faecalis ATCC 29212 and Escherichia coli ATCC 25922 were used as quality control strains.

Two strains of MRSP were exposed to several dilutions of the combination of polymyxin B and miconazole for several days to see whether rapid development of resistance occurs. In short, a fresh series of $3 \mathrm{~mL}$ Mueller Hinton broth (Becton Dickinson, Breda, The Netherlands) was prepared daily containing concentrations of 0.25 , $0.5,1,2$ and 4 times the MIC of the combination of polymyxin B and miconazole for these strains (in the 1:43.5 ratio).

Fresh cultures of two strains with MICs of the combination of miconazole and polymyxin $B$ of 11.2 and $0.26 \mu \mathrm{g} / \mathrm{mL}$, respec- tively (which corresponds to a $5 \times 10^{4}$-fold dilution of the commercial product), were used to inoculate $5 \mathrm{~mL}$ brain-heart infusion broth tubes (BioTrading, Mijdrecht, The Netherlands). Tubes were incubated overnight at $37^{\circ} \mathrm{C}$ and purity was checked. The next day, $10 \mu \mathrm{L}$ of the broth was used to inoculate broth tubes containing the series of concentrations of miconazole and polymyxin $B$ as described above, and one tube containing no antimicrobials was used as a growth control. After incubation at $37^{\circ} \mathrm{C}$ for $18-24 \mathrm{~h}$, the broth tubes were visually evaluated for bacterial growth. The tube containing the highest concentration of antimicrobials and showing growth was used to inoculate the next series of broth tubes as described above. This was repeated for seven consecutive incubations, and MIC values were determined on the isolates obtained from the last incubation as described above.

\section{Results}

The results of the antimicrobial susceptibility testing are presented in Tables 1-4. For the broth microdilution assay, all MIC values of the quality control strains were within the acceptable ranges, as described by CLSI. ${ }^{22}$ In general, resistance to multiple antimicrobial classes was commonly identified among the MRSA and MRSP isolates (Tables 1 and 2).

The MIC values for miconazole and polymyxin B were in the range of $4-8$ and $8-64 \mu \mathrm{g} / \mathrm{mL}$, respectively, for the MRSA strains (Table 3), and in the range of 1-2 and 0.25$4 \mu \mathrm{g} / \mathrm{mL}$, respectively, for the MRSP strains (Table 4). The monomodal distribution of the MIC values suggests no acquired resistance in any of the tested MRSA or MRSP strains towards both miconazole and polymyxin B.

All MIC values for the pure miconazole-polymyxin $B$ combination were in the range of 2.8/0.064 and 22.5/ $0.52 \mu \mathrm{g} / \mathrm{mL}$ for both MRSA and MRSP. The MIC values for the miconazole-polymyxin B combination in the commercial product were in a similar range, even though these MIC values tended to be slightly higher than for the pure miconazole-polymyxin B combination for the MRSA strains. Nevertheless, $\mathrm{MIC}_{90}$ values of the pure combination of agents and of the combination of agents in a 1:43.5 ratio were at least 1024 times lower than the concentrations present in the previously mentioned commercial product for MRSA and MRSP strains.

While testing the emergence of resistance, the strains showed growth in the tubes with 0.25 times the MIC of miconazole and polymyxin B after days 1 and 4 and in tubes with a concentration of 0.25 and 0.5 times the MIC of miconazole and polymyxin B after days 2, 3, 5, 6 and 7. All MICs of the strains that were exposed to the combination of miconazole and polymyxin B for 7 days were in the same range as those of the strains prior to exposure.

\section{Discussion}

Treatment of infections caused by multiresistant MRSP and MRSA strains is a challenge for veterinary medicine. Our results confirm previous reports showing that canine MRSA and MRSP strains are often resistant towards macrolides, tetracyclines and certain fluoroquinolones and aminoglycosides. Resistance is also observed against certain antimicrobials that are more commonly used in human medicine, such as fucidic acid and mupirocin. $7,25,26$

(C) 2012 The Authors. Veterinary Dermatology (c) 2012 ESVD and ACVD, Veterinary Dermatology, 23, 381-e70. 
Table 1. Distribution of minimal inhibitory concentrations (MICs) of various antimicrobial agents against canine meticillin-resistant Staphylococcus aureus (MRSA) isolates using the Sensititre panel NLV65

\begin{tabular}{|c|c|c|c|c|c|c|c|c|c|c|c|c|c|c|}
\hline \multirow[b]{2}{*}{ Antimicrobial agent } & \multicolumn{14}{|c|}{ Number of MRSA strains with MIC $(\mu \mathrm{g} / \mathrm{mL})^{*}$} \\
\hline & $\leq 0.12$ & $\leq 0.25$ & 0.25 & $\leq 0.5$ & 0.5 & 1 & 2 & 4 & 8 & 16 & 32 & $>32$ & 64 & $>64$ \\
\hline Erythromycin & & 1 & & & 6 & & & 1 & & & & 16 & & \\
\hline Clindamycin & & 9 & & & 3 & 1 & 1 & & & & & 10 & & \\
\hline Rifampicint & & 23 & & & & & & & & & & 1 & & \\
\hline Fusidate & & 19 & & & & & 2 & 1 & 2 & & & & & \\
\hline Gentamicin & & & & 15 & & 3 & 1 & & 1 & & 3 & & & 1 \\
\hline Amikacin & & & & & & 2 & 5 & 7 & 4 & 5 & 1 & & & \\
\hline Neomycin & & & & 3 & & 2 & 3 & 1 & 2 & 3 & 3 & & 3 & 4 \\
\hline Ciprofloxacin & & & & 8 & & & & 1 & & 4 & 3 & & 4 & 4 \\
\hline Tetracycline & & & & 11 & & & 1 & 1 & 1 & 5 & 2 & & 3 & \\
\hline Mupirocin & & & & 23 & & & & 1 & & & & & & \\
\hline Sulfa/trim $(20 / 1) \ddagger$ & 17 & & 3 & & 2 & & & 1 & & 1 & & & & \\
\hline Linezolid & & & & 1 & & 5 & 16 & 2 & & & & & & \\
\hline
\end{tabular}

*The vertical bars represent wild-type cut-off values for $S$. aureus as described by The European Committee on Antimicrobial Susceptibility Testing ${ }^{21}$.

tWild type strains show rifampicin MIC values smaller than or equal to $0.03 \mu \mathrm{g} / \mathrm{mL}$

‡Trimethoprim MIC values are shown, Sulfa/trim: sulfamethoxazole/trimethoprim.

Table 2. Distribution of MICs of various antimicrobial agents against canine meticillin-resistant S. pseudintermedius (MRSP) isolates using the Sensititre panel NLV65

\begin{tabular}{|c|c|c|c|c|c|c|c|c|c|c|c|c|c|c|}
\hline \multirow[b]{2}{*}{ Antimicrobial agent } & \multicolumn{14}{|c|}{ Number of MRSP strains with MIC $(\mu \mathrm{g} / \mathrm{mL})^{*}$} \\
\hline & $\leq 0.12$ & $\leq 0.25$ & 0.25 & $\leq 0.5$ & 0.5 & 1 & 2 & 4 & 8 & 16 & 32 & $>32$ & 64 & $>64$ \\
\hline Erythromycin & & 4 & & & 4 & & & & & & & & 42 & \\
\hline Clindamycin & & 7 & & & 1 & 1 & & & & & & & 41 & \\
\hline Rifampicint & & 50 & & & & & & & & & & & & \\
\hline Fusidate & & 45 & & & 2 & 2 & 1 & & & & & & & \\
\hline Gentamicin & & & & 5 & & & 1 & 5 & 5 & 29 & 4 & & & 1 \\
\hline Amikacin & & & & & & 6 & 26 & 16 & 1 & & & & 1 & \\
\hline Neomycin & & & & 7 & & & & 4 & 30 & 7 & 2 & & & \\
\hline Ciprofloxacin & & & & 3 & & 2 & & & & 1 & 4 & & 40 & \\
\hline Tetracycline & & & & 14 & & 1 & & & & 1 & 1 & & 25 & 8 \\
\hline Mupirocin & & & & 48 & & 2 & & & & & & & & \\
\hline Sulfa/trim $(20 / 1) \ddagger$ & & & & 4 & & 1 & 1 & & 32 & 12 & & & & \\
\hline Linezolid & & & & & & 1 & 46 & 3 & & & & & & \\
\hline
\end{tabular}

* The vertical bars represent wild type cut-off values for $S$. aureus as described by The European Committee on Antimicrobial Susceptibility Testing ${ }^{21}$.

†Wild type strains show rifampicin MIC values smaller than or equal to $0.03 \mu \mathrm{g} / \mathrm{mL}$.

fTrimethoprim MIC values are shown, Sulfa/trim: sulfamethoxazole/trimethoprim.

Table 3. Distribution of MICs of miconazole, polymyxin B, the pure miconazole-polymyxin B combination and the commercial miconazole-polymyxin B combination in Surolan ${ }^{\circledR}$ (Elanco Animal Health, Greenfield, IN, USA) against canine MRSA isolates using a broth microdilution assay

\begin{tabular}{|c|c|c|c|c|c|c|c|c|c|c|c|}
\hline \multirow[b]{2}{*}{ Antimicrobial agent } & \multicolumn{11}{|c|}{ Number of MRSA strains with MIC $(\mu \mathrm{g} / \mathrm{mL})^{*}$} \\
\hline & 0.25 & 0.5 & 1 & 2 & 4 & 8 & 16 & 32 & 64 & 128 & $>128$ \\
\hline Miconazole & & & & & 20 & 4 & & & & & \\
\hline \multirow[t]{2}{*}{ Polymyxin B } & & & & & & 1 & 2 & 15 & 6 & & \\
\hline & $0.7 / 0.016$ & $1.4 / 0.032$ & $2.8 / 0.064 \dagger$ & $5.6 / 0.13$ & $11.2 / 0.26$ & $22.5 / 0.52 \ddagger$ & $45 / 1$ & $90 / 2$ & $180 / 4$ & $360 / 8$ & $>360 / 8$ \\
\hline Miconazole-polymyxin B & & & 5 & 13 & 3 & 3 & & & & & \\
\hline Surolan§ & & & & 1 & 9 & 14 & & & & & \\
\hline
\end{tabular}

*Miconazole-polymyxin B concentrations are shown.

†This value corresponds to an 8192-fold dilution of the miconazole-polymyxin B concentration in Surolan ${ }^{\circledR}$.

$\ddagger$ This value corresponds to a 1024-fold dilution of the miconazole-polymyxin B concentration in Surolan ${ }^{\circledR}$.

$\S$ These MIC values correspond to the miconazole-polymyxin B concentrations in Surolan ${ }^{\circledR}$.

The MIC values for miconazole and polymyxin $B$ were in the range of $4-8$ and $8-64 \mu \mathrm{g} / \mathrm{mL}$, respectively, for MRSA strains, and in the range of $1-2$ and $0.25-4 \mu \mathrm{g} / \mathrm{mL}$,

(C) 2012 The Authors. Veterinary Dermatology

(c) 2012 ESVD and ACVD, Veterinary Dermatology, 23, 381-e70. respectively, for MRSP strains. Similar ranges of MIC values for miconazole have been reported in $S$. aureus and a single SIG strain. ${ }^{27-29}$ For polymyxin B, an MIC 
Table 4. Distribution of MICs of miconazole, polymyxin B, the pure miconazole-polymyxin B combination and the commercial miconazolepolymyxin B combination in Surolan ${ }^{\circledR}$ (Elanco Animal Health) against canine MRSP isolates using a broth microdilution assay

\begin{tabular}{|c|c|c|c|c|c|c|c|c|c|c|c|}
\hline \multirow[b]{2}{*}{ Antimicrobial agent } & \multicolumn{11}{|c|}{ Number of MRSP strains with MIC $(\mu \mathrm{g} / \mathrm{mL})^{*}$} \\
\hline & 0.25 & 0.5 & 1 & 2 & 4 & 8 & 16 & 32 & 64 & 128 & $>128$ \\
\hline Miconazole & & & 19 & 31 & & & & & & & \\
\hline \multirow[t]{2}{*}{ Polymyxin B } & 2 & 4 & 8 & 33 & 3 & & & & & & \\
\hline & $0.7 / 0.016$ & $1.4 / 0.032$ & $2.8 / 0.064 \S$ & $5.6 / 0.13$ & $11.2 / 0.26$ & $22.5 / 0.52 \dagger$ & $45 / 1$ & $90 / 2$ & $180 / 4$ & $360 / 8$ & $>360 / 8$ \\
\hline Miconazole-polymyxin B & & & 1 & 6 & 39 & 3 & & & & & 1 \\
\hline Surolan $\neq$ & & & 1 & 6 & 39 & 3 & & & & & 1 \\
\hline
\end{tabular}

*Miconazole-polymyxin B concentrations are shown.

†This value corresponds to a 1024-fold dilution of the miconazole-polymyxin B concentration in Surolan ${ }^{\circledR}$.

$\ddagger$ These MIC values correspond to the miconazole-polymyxin B concentrations in Surolan ${ }^{\circledR}$.

$\S$ This value corresponds to a 8192-fold dilution of the miconazole/polymyxin concentration in Surolan ${ }^{\circledR}$.

value of $23 \mu \mathrm{g} / \mathrm{mL}$ for a single MRSA strain has been described recently. ${ }^{30}$ The slightly lower MIC values of polymyxin B for S. pseudintermedius might be a species-specific characteristic, because polymyxin susceptibility has been used to discriminate $S$. aureus from $S$. intermedius group in the past. ${ }^{31}$ Considering the monomodal distribution of the MIC values, there were no indications to suggest acquired resistance in any of the tested MRSA or MRSP strains towards miconazole or polymyxin $B$, despite resistance of the tested isolates to many other antimicrobials. Even though staphylococci could be considered intrinsically resistant to polymyxin B and miconazole in the case of systemic treatment of Staphylococcus infections, these products may be effective for topical treatment because the concentrations achieved by systemic therapy are markedly lower than those obtained by local treatment. This hypothesis is supported by the fact that $\mathrm{MIC}_{90}$ values of the pure combination of agents and of the combination of agents in Surolan ${ }^{\circledR}$ were at least 1024 times lower than the concentration of both polymyxin B and miconazole in Surolan ${ }^{\circledR}$ for MRSA and MRSP strains.

After exposing two MRSP strains to concentrations below the MIC for 7 days, no change in the MICs could be observed. This suggests that there is not a rapid development of resistance against this combination of products. However, this experimental set-up cannot be used to predict the emergence of all resistance mechanisms.

Using the miconazole/polymyxin B ratio as used in the commercial product, there were no indications of enhanced in vitro activity of the combination of both products. Even though Pietschmann et al. ${ }^{28}$ reported the absence of synergy between miconazole and polymyxin B for an S. intermedius group strain, synergism was observed between both agents for Escherichia coli, Pseudomonas aeruginosa and Malassezia pachydermatis. Considering the higher in vitro antimicrobial activity of miconazole compared with polymyxin B for the tested MRSA and MRSP strains and considering the fact that in the commercial product the miconazole concentration is about 43 times higher than the polymyxin concentration, the in vitro anti-MRSA and anti-MRSP activity of Surolan ${ }^{\circledR}$ can be attributed mainly to miconazole.

The present in vitro results suggest that even though the active substances in Surolan ${ }^{\circledR}$ primarily target fungi and Gram-negative bacteria, this combination of antimicrobial agents also holds features for topical treatment of canine otitis caused by MRSA and MRSP. The in vivo effectiveness of Surolan ${ }^{\circledR}$ in treating canine MRSA-mediated otitis therefore needs further research.

\section{References}

1. Devriese LA, Vancanneyt M, Baele M et al. Staphylococcus pseudintermedius sp. nov., a coagulase-positive species from animals. Int J Syst Evol Microbiol 2005; 55: 1569-1573.

2. Devriese LA, Hermans K, Baele M et al. Staphylococcus pseudintermedius versus Staphylococcus intermedius. Vet Microbiol 2009; 133: 206-207

3. Cox HU, Hoskins JD, Newman SS et al. Temporal study of staphylococcal species on healthy dogs. Am J Vet Res 1988; 49: 747-751.

4. Talan DA, Staatz D, Staatz A et al. Staphylococcus intermedius in canine gingiva and canine-inflicted human wound infections: laboratory characterization of a newly recognized zoonotic pathogen. J Clin Microbiol 1989; 27: 78-81.

5. Weese JS, van Duijkeren E. Methicillin-resistant Staphylococcus aureus and Staphylococcus pseudintermedius in veterinary medicine. Vet Microbiol 2010; 140: 418-429.

6. Riegel P, Jesel-Morel L, Laventie B et al. Coagulase-positive Staphylococcus pseudintermedius from animals causing human endocarditis. Int J Med Microbiol 2011; 301: 237-239.

7. Perreten V, Kadlec K, Schwarz S et al. Clonal spread of methicillinresistant Staphylococcus pseudintermedius in Europe and North America: an international multicentre study. J Antimicrob Chemother 2010; 65: 1145-1154.

8. Kadlec K, Schwarz S, Perreten V et al. Molecular analysis of methicillin-resistant Staphylococcus pseudintermedius of feline origin from different European countries and North America. J Antimicrob Chemother 2010; 65: 1826-1828.

9. Guardabassi L, Ghibaudo G, Damborg P. In vitro antimicrobial activity of a commercial ear antiseptic containing chlorhexidine and Tris-EDTA. Vet Dermatol 2010; 21: 282-286.

10. Storm DR, Rosenthal KS, Swanson PE. Polymyxin and related peptide antibiotics. Annu Rev Biochem 1977; 46: 723-763.

11. Rosenthal KS, Storm DR. Disruption of the Escherichia coli outer membrane permeability barrier by immobilized polymyxin $B$. J Antibiot (Tokyo) 1977; 30: 1087-1092.

12. Schwartz SN, Medoff G, Kobayashi GS et al. Antifungal properties of polymyxin $B$ and its potentiation of tetracycline as an antifungal agent. Antimicrob Agents Chemother 1972; 2: 3640.

13. Van den Bossche H, Willemsens G, Cools W et al. Biochemical effects of miconazole on fungi II. Inhibition of ergosterol biosynthesis in Candida albicans. Chem Biol Interact 1978; 21: 59-78. 
14. Nobre LS, Todorovic S, Tavares AF et al. Binding of azole antibiotics to Staphylococcus aureus flavohemoglobin increases intracellular oxidative stress. J Bacterio/ 2010; 192: 1527-1533.

15. Engelen M, De Bock M, Hare J et al. Effectiveness of an otic product containing miconazole, polymyxin $\mathrm{B}$ and prednisolone in the treatment of canine otitis externa: multi-site field trial in the US and Canada. Int J App/ Res Vet Med 2010; 8: 21-30.

16. Hariharan $H$, McPhee L, Heaney $S$ et al. Antimicrobial drug susceptibility of clinical isolates of Pseudomonas aeruginosa. Can Vet J 1995; 36: 166-168.

17. Vannuffel $\mathrm{P}$, Gigi J, Ezzedine $\mathrm{H}$ et al. Specific detection of methicillin-resistant Staphylococcus species by multiplex PCR. J Clin Microbiol 1995; 33: 2864-2867.

18. Khanna T, Friendship R, Dewey $C$ et al. Methicillin resistant Staphylococcus aureus colonization in pigs and pig farmers. Vet Microbio/ 2008; 128: 298-303.

19. Bannoehr J, Franco A, lurescia M et al. Molecular diagnostic identification of Staphylococcus pseudintermedius. J Clin Microbiol 2009; 47: 469-471.

20. Nienhoff U, Kadlec K, Chaberny IF et al. Transmission of methicillin-resistant Staphylococcus aureus strains between humans and dogs: two case reports. J Antimicrob Chemother 2009; 64: 660-662.

21. The European Committee on Antimicrobial Susceptibility Testing (EUCAST) website. Available at: http://217.70.33.99/Eucast2/ SearchController/search.jsp?action=init. Accessed 15 April 2011.

22. CLSI. Performance Standards for Antimicrobial Disk and Dilution Susceptibility Tests for Bacteria Isolated from Animals. Approved Standard, 3rd edition. M31-A3. Wayne, PA: Clinical and Laboratory Standards Institute, 2008; 24-35.

23. Turnidge J, Paterson DL. Setting and revising antibacterial susceptibility breakpoints. Clin Microbiol Rev 2007; 20: 391-408.
24. CLSI. Generation, Presentation and Application of Antimicrobial Susceptibility Test Data for Bacteria of Animal Origin; A Report. Document X-08. Wayne, PA: Clinical and Laboratory Standards Institute, 2011; 5-9.

25. Ruscher C, Lübke-Becker A, Wleklinski CG et al. Prevalence of methicillin-resistant Staphylococcus pseudintermedius isolated from clinical samples of companion animals and equidaes. Vet Microbiol 2009; 136: 197-201.

26. Nienhoff U, Kadlec K, Chaberny IF et al. Methicillin-resistant Staphylococcus pseudintermedius among dogs admitted to a small animal hospital. Vet Microbiol 2011; 150: 191-197.

27. Sud IJ, Feingold DS. Action of antifungal imidazoles on Staphylococcus aureus. Antimicrob Agents Chemother 1982; 22: 470474.

28. Pietschmann S, Hoffmann K, Voget M et al. Synergistic effects of miconazole and polymyxin B on microbial pathogens. Vet Res Commun 2008; 33: 489-505.

29. Jones BM, Geary I, Lee ME et al. Comparison of the in vitro activities of fenticonazole, other imidazoles, metronidazole, and tetracycline against organisms associated with bacterial vaginosis and skin infections. Antimicrob Agents Chemother 1989; 33: 970-972.

30. van der Linden DS, Short D, Dittmann A et al. Synergistic effects of ovine-derived cathelicidins and other antimicrobials against Escherichia coli 0157:H7 and Staphylococcus aureus 1056 MRSA. Biotechnol Lett 2009; 31: 1265-1267.

31. Quinn P, Carter M, Markey B et al. (1994) Staphylococcus species. In: Clinical Veterinary Microbiology, 1st edition. Edinburgh, Mosby: 125.

\section{Résumé}

Contexte - Les infections liées aux Staphylococcus aureus résistants à la méticilline (MRSA) et aux Staphylococcus pseudintermedius résistants à la méticilline (MRSP) sont rapportées de plus en plus fréquemment chez le chien et peuvent être isolées à partir d'infections auriculaires.

Hypothèses/Objectifs - le principal objectif de notre étude était de déterminer l'activité antimicrobienne in vitro du miconazole, de la polymyxine B et d'une association des deux contre 24 isolats de MRSA et 50 isolats de MRSP canins. Les valeurs de CMI de 12 autres agents antimicrobiens ont également été déterminées.

Méthodes - Toutes les valeurs de CMI ont été déterminées par test de microdilution.

Résultats - Une résistance acquise a été trouvée pour tous les agents testés sauf pour le linezolide, le miconazole et la polymyxine B. Les valeurs de MIC pour le miconazole et la polymyxine B contre les MRSA étaient respectivement dans les limites de $4-8 \mu \mathrm{g} / \mathrm{mL}$ et $8-64 \mu \mathrm{g} / \mathrm{mL}$. Les valeurs de MIC pour le miconazole et la polymyxine $B$ contre les MRSP étaient respectivement dans les limites de $1-2 \mu \mathrm{g} / \mathrm{mL}$ et $0.25-4 \mu \mathrm{g} / \mathrm{mL}$. Avec une association de miconazole et de polymyxine $\mathrm{B}$, il n'y avait aucune preuve d'augmentation de l'activité in vitro (i.e. de synergie) des deux produits. Quoi qu'il en soit, les valeurs de $\mathrm{MIC}_{90}$ de la combinaison de ces agents antimicrobiens et d'un produit commercial contenant les deux agents étaient au moins 1000 fois plus faible que la concentration présente dans le produit commercial.

Conclusions et importance clinique - Ces résultats montrent que l'utilisation topique d'une combinaison de miconazole et de polymyxine $\mathrm{B}$ à un ratio 43.5 : 1 peut avoir une efficacité dans le traitement des otites externes médiées par les MRSA et associées aux MRSP chez le chien.

\section{Resumen}

Introduccion - Staphylococcus aureus resistente a Meticilina (MRSA) e infecciones por S. pseudintermedius resistente a meticilina (MRSP) se observan cada vez con más frecuencia en perros y se pueden aislar de infecciones del oído.

Hipótesis/objetivos - el objetivo principal del estudio fue investigar la actividad antimicrobiana in vitro de miconazol, polimixina B y de una combinación de ambos contra 24 MRSA caninos y 50 aislados caninos de MRSP. También se determinaron los valores de MIC de 12 otros agentes antimicrobianos.

Métodos - los valores MIC fueron determinados según un análisis de microdilución de la suspensión.

Resultados - se encontró resistencia adquirida a todos los agentes probados, a excepción de linezolid, miconazol y de polimixina B. Los valores de MIC para el miconazol y la polimixina B contra MRSA estaban en el rango de $4-8 \mu \mathrm{g} / \mathrm{mL}$ y $8-64 \mu \mathrm{g} / \mathrm{mL}$ respectivamente; los valores de MIC para miconazol y polimixina B frente a MRSP fueron del rango de $1-2 \mu \mathrm{g} / \mathrm{mL}$ y de $0.25-4 \mu \mathrm{g} / \mathrm{mL}$ respectivamente. Usando una combinación miconazol y polimixina $B$, no hubo evidencia de actividad sinérgica in vitro. Sin embargo, los valores 
$\mathrm{MIC}_{90}$ de la combinación de estos agentes antimicrobianos y de un producto comercial que contenía ambos agentes fueron por lo menos 1000 veces más bajas que la concentración presente en el producto comercial.

Conclusiones e importancia clínica - estos resultados indican que el uso tópico de una combinación de miconazol/polimixina $B$ en un cociente de $43.5: 1$ puede tener potencial para el tratamiento de la otitis externa mediada por MRSA y MRSP.

\section{Zusammenfassung}

Hintergrund - Infektionen durch Methicillin-resistente Staphylococcus aureus (MRSA) und Methicillinresistente Staphylococcus pseudintermedius (MRSP) werden in zunehmendem Maße bei Hunden beschrieben und diese Keime können bei Ohrinfektionen isoliert werden.

Hypothese /Ziele - Das wesentliche Ziel dieser Studie war es, die antimikrobielle in vitro Aktivität von Mikonazol, Polymyxin B und einer Kombination aus beiden Wirkstoffen bei der Behandlung von 24 caninen MRSA und 50 caninen MRSP Isolaten zu untersuchen. Die MIC Werte von 12 anderen antimikrobiellen Wirkstoffen wurden ebenfalls bestimmt.

Methoden - Alle MIC Werte wurden mit Hilfe eines Bouillon-Mikroverdünnungs-Assays bestimmt. Ergebnisse - Eine erworbene Resistenz wurde gegen alle untersuchten Wirkstoffe, außer gegen Linelozid, Mikonazol und Polymyxin B festgestellt. Die MIC Werte für Mikonazol und Polymyxin B gegen MRSA lagen im Bereich von 4-8 $\mu \mathrm{g} / \mathrm{mL}$ beziehungsweise 8-64 $\mu \mathrm{g} / \mathrm{mL}$, MIC Werte für Mikonazol und Polymyxin gegen MRSP lagen im Bereich von 1-2 $\mu \mathrm{g} / \mathrm{mL}$ beziehungsweise $0.25-4 \mu \mathrm{g} / \mathrm{mL}$. Trotz der Verwendung einer Kombination von Mikonazol und Polymyxin B gab es keine Evidenz für eine gesteigerte in vitro Aktivität der Kombination beider Produkte (im Sinne einer Synergie). Trotz allem waren die $\mathrm{MIC}_{90}$ Werte dieser Kombination der antimikrobiellen Wirkstoffe und eines kommerziellen Produkts, welches beide Wirkstoffe beinhaltet, mindestens 1000-fach niedriger als die Konzentrationen, die im kommerziellen Produkt vorkommen.

Zusammenfassung und klinische Bedeutung - Diese Ergebnisse weisen darauf hin, dass die topische Verwendung von Mikonazol / Polymyxin B im Verhältnis 43,5 : 1 eine mögliche Behandlungsform für Otitis externa aufgrund von MRSA und MRSP bei Hunden darstellt.

\section{要約}

背景ーメチシリン而性 Staphylococcus aureus (MRSA) とメチシリン耐性 Staphylococcus pseudintermedius (MRSP) 感染の報告は犬で増加しており、耳の感染症からも分離されている。

仮説/目的－この研究の主な目的は, 犬から分離した MRSA24 株と MRSP50 株に対するミコナゾール、ポリミ キシン B、あるいは両方の組み合わせを用いて in vitroでの抗菌作用を調査することである。その他の 12 種類の抗菌物質についてもMIC 值を測定した。

方法 - すべての MIC 值は微量液体気釈法によって決定した

結果 - 獲得された而性はリネゾリド、ミコナゾール、ポリミキシン B を除くすべての検査した物質で認めら れた。ミコナゾールとポリミキシンB の MRSA に対する MIC 值はそれぞれ $1-2 \mu \mathrm{g} / \mathrm{mL}$ と $0.25-4 \mu \mathrm{g} / \mathrm{mL}$ の範囲で あった。ミコナゾールとポリミキシン B の組み合わせの使用では、両方の合剂に in vitro での活性の増加 (つまり、相乗効果) の証拠は認められなかった。それにも関らず、これらの抗菌物質の合剤および両方の 物質を含んでいる市販の製品の $\mathrm{MIC}_{90}$ 值は市販の製品より少なくとも 1000 倍以上は低かった。

結論と臨床的な重要性 -これらの結果はミコナゾール/ポリミキシンを 43.5:1の比率に組み合わせた合剤 が，犬のMRSA 介在性、MRSP 関連性外耳炎の治療に対して可能性があることを示唆した。

\section{摘要}

背景 - 越来越多关于犬感染耐甲氧西林金黄色葡萄球菌 (MRSA) 和耐甲氧西林假中间型葡萄球菌 (MRSP) 的报道, 二者可能是感染耳道的菌株。

假说/目的 - 当前研究的主要目的是研究咪康唑、多粘菌素B和两者结合对 24 只犬的MRSP和 50 只犬的MRSA菌株的 体外抗菌活性。同时确定其他12种抗菌药物的MIC值。

方法 - 培养液微量稀释法确定所有MIC值。

结果 - 除利奈唑䀦、咪康唑和多粘菌素B之外, 其他测试药物均存在耐药性。咪康唑与多粘菌素B抗MRSA的MIC 值分别在 4-8 $\mu \mathrm{g} / \mathrm{mL}$ 和 $8-64 \mu \mathrm{g} / \mathrm{mL}$ 范围内, 咪康唑与多粘菌素B抗 MRSP 的MIC值分别在 $1-2 \mu \mathrm{g} / \mathrm{mL}$ 和 $0.25-4 \mu \mathrm{g} / \mathrm{mL}$ 范围内。联合使用咪康唑与多粘菌素B, 没有证据显示这两种产品的结合 (即协同)能使体外活性增 强。不过, 这两种抗菌药物联合及包含两者的商业产品的MIC 90 值, 比商业产品现有浓度至少低1000倍。

结论和临床意义 - 这些结果表明, 以43.5:1的比例联合的咪康唑/多粘菌素B外用药, 有能力治疗MRSA-介导和 MRSP-相关犬外耳炎。 